\title{
Sulfur poisoning and regeneration of the Ag/-Al2O3 catalyst for H2-assisted SCR of NOx by ammonia
}

Doronkin, Dmitry E.; Khan, Tuhin Suvra; Bligaard, Thomas; Fogel, Sebastian; Gabrielsson, Pär; Dahl, Søren

Published in:

Applied Catalysis B: Environmental

Link to article, DOI:

10.1016/j.apcatb.2012.01.002

Publication date:

2012

Link back to DTU Orbit

Citation (APA):

Doronkin, D. E., Khan, T. S., Bligaard, T., Fogel, S., Gabrielsson, P., \& Dahl, S. (2012). Sulfur poisoning and regeneration of the Ag/-Al2O3 catalyst for $\mathrm{H} 2$-assisted SCR of NOx by ammonia. Applied Catalysis B:

Environmental, 117-118, 49-58. https://doi.org/10.1016/j.apcatb.2012.01.002

\section{General rights}

Copyright and moral rights for the publications made accessible in the public portal are retained by the authors and/or other copyright owners and it is a condition of accessing publications that users recognise and abide by the legal requirements associated with these rights.

- Users may download and print one copy of any publication from the public portal for the purpose of private study or research.

- You may not further distribute the material or use it for any profit-making activity or commercial gain

- You may freely distribute the URL identifying the publication in the public portal 


\section{Sulfur poisoning and regeneration of the $\mathrm{Ag} / \gamma-\mathrm{Al}_{2} \mathrm{O}_{3}$ catalyst for $\mathrm{H}_{2}$-assisted $\mathrm{SCR}$}

of $\mathrm{NO}_{\mathrm{x}}$ by ammonia

Dmitry E. Doronkin ${ }^{1}$, Tuhin Suvra Khan ${ }^{2}$, Thomas Bligaard ${ }^{3}$, Sebastian Fogel ${ }^{1,4}$, Pär Gabrielsson $^{4}$, Søren Dahl ${ }^{1}$

${ }^{1}$ Center for Individual Nanoparticle Functionality (CINF), Department of Physics, Technical University of Denmark, Fysikvej 307, 2800 Kgs. Lyngby, Denmark ${ }^{2}$ Center of Atomic-scale Materials Design (CAMD), Department of Physics, Technical University of Denmark, Fysikvej 307, 2800 Kgs. Lyngby, Denmark

${ }^{3}$ SUNCAT Center for Interface Science and Catalysis, SLAC National Accelerator Laboratory, Menlo Park, CA 94025, U.S.A.

${ }^{4}$ Haldor Topsøe A/S, Nymøllevej 55, 2800 Kgs. Lyngby, Denmark

* Corresponding author: tel.: +45-4525-3275, e-mail: $\underline{d m d o @ f y s i k . d t u . d k}$

Abstract. Sulfur poisoning and regeneration mechanisms for a $2 \% \mathrm{Ag} / \gamma-\mathrm{Al}_{2} \mathrm{O}_{3}$ catalyst for the $\mathrm{H}_{2}$-assisted selective catalytic reduction of $\mathrm{NO}_{\mathrm{x}}$ by $\mathrm{NH}_{3}$ are investigated. The catalyst has medium sulfur tolerance at low temperatures, however a good capability of regeneration at $670{ }^{\circ} \mathrm{C}$ under lean conditions when $\mathrm{H}_{2}$ is present. These heating conditions can easily be established during soot filter regeneration. Furthermore, two types of active sites could be identified with different regeneration capabilities, namely finely dispersed $\mathrm{Ag}$ and larger Ag nanoparticles. The most active sites are associated with the finely dispersed Ag. These sites are irreversibly poisoned and cannot be regenerated under driving conditions. On the other hand the larger Ag nanoparticles are reversibly poisoned by direct $\mathrm{SO}_{\mathrm{x}}$ adsorption. The interpretation of the data is supported by DFT calculations. 
Keywords: $\mathrm{Ag} / \mathrm{Al}_{2} \mathrm{O}_{3} ; \mathrm{SO}_{2} ; \mathrm{NO}_{\mathrm{x}} \mathrm{SCR}$; poisoning; regeneration

\section{Introduction}

Selective catalytic reduction (SCR) is the leading $\mathrm{NO}_{\mathrm{x}}$ control technique for diesel vehicles with ammonia used as a reductant. Commonly used catalysts are vanadia-based catalysts and $\mathrm{Cu}$ and $\mathrm{Fe}$-containing zeolites. However, none of the systems demonstrate high thermal durability together with a good activity throughout the broad temperature region from 150 to $550{ }^{\circ} \mathrm{C}$ which is needed for vehicle applications [1]. Therefore, research of novel non-toxic, inexpensive and durable catalytic systems for $\mathrm{NH}_{3}-\mathrm{SCR}$ is still an important focus area.

Recently two research groups suggested to use $\mathrm{Ag} / \mathrm{Al}_{2} \mathrm{O}_{3}$, which is a well-known catalyst for $\mathrm{NO}_{\mathrm{x}} \mathrm{SCR}$ by hydrocarbons (HC-SCR), for SCR of $\mathrm{NO}_{\mathrm{x}}$ by ammonia or urea with co-feeding hydrogen, resulting in nearly $90 \% \mathrm{NO}_{\mathrm{x}}$ conversion at temperatures as low as $200{ }^{\circ} \mathrm{C}[2,3]$. Still, one of the major obstacles for the application of $\mathrm{Ag} / \mathrm{Al}_{2} \mathrm{O}_{3}$ for $\mathrm{NO}_{\mathrm{x}}$ SCR by ammonia is its rather poor sulfur tolerance [4]. A catalyst of $2 \% \mathrm{Ag} / \mathrm{Al}_{2} \mathrm{O}_{3}$ demonstrated a decrease in $\mathrm{H}_{2}$-assisted $\mathrm{NO}_{\mathrm{x}}$ conversion by urea from $50 \%$ to $30 \%$ after 20 hours on stream in the presence of $50 \mathrm{ppm} \mathrm{SO}_{2}$ at $250{ }^{\circ} \mathrm{C}$. This is a rather good result considering the very high GHSV=380 $000 \mathrm{~h}^{-1}$ in the tests. However, the large amount of hydrogen $\left(0.5 \%, 5: 1 \mathrm{H}_{2}: \mathrm{NO}\right)$ used in this study is probably inacceptable for application in diesel vehicles because such a large consumption of hydrogen leads to a high "fuel penalty" [5].

A significant amount of data on sulfur tolerance of $\mathrm{Ag} / \mathrm{Al}_{2} \mathrm{O}_{3}$ catalysts exists for $\mathrm{NO}_{\mathrm{x}}$ SCR by hydrocarbons. Meunier and Ross [6] observed strong deactivation of a $1.2 \% \mathrm{Ag} / \mathrm{Al}_{2} \mathrm{O}_{3}$ catalyst for propene-SCR by $100 \mathrm{ppm} \mathrm{SO}_{2}$ in the feed. It is noteworthy 
that the authors were able to recover most of the catalyst activity by treatment in $10 \% \mathrm{H}_{2} / \mathrm{Ar}$ at $650{ }^{\circ} \mathrm{C}$ or heating in the reaction mixture at $750{ }^{\circ} \mathrm{C}$. Park and Boyer [7] compared the catalytic behavior of $2 \%$ and $8 \% \mathrm{Ag} / \mathrm{Al}_{2} \mathrm{O}_{3}$ catalysts in the presence of $\mathrm{SO}_{2}$ and concluded that high $\mathrm{Ag}$ loadings may be preferrential for making a sulfur tolerant catalyst. The authors demonstrated prominent activation of $8 \% \mathrm{Ag} / \mathrm{Al}_{2} \mathrm{O}_{3}$ by $\mathrm{SO}_{2}$ in the feed and ascribed that to the formation of a very active silver sulfate phase. When estimating the $\mathrm{SO}_{2}$ tolerance of $\mathrm{Ag} / \mathrm{Al}_{2} \mathrm{O}_{3}$ catalysts attention should be given also to the process temperature. Satokawa and coworkers [8] showed a clear dependence of the propane-SCR temperature on the deactivation degree with permanent catalyst deactivation at $\mathrm{T}<500{ }^{\circ} \mathrm{C}$ and futhermore the ability to partially regenerate the catalyst by heating to $600{ }^{\circ} \mathrm{C}$, even without removing low amounts ( $\left.1 \mathrm{ppm}\right)$ of $\mathrm{SO}_{2}$ from the feed. Further studies [8] of sulfation-regeneration mechanisms included obtaining $\mathrm{SO}_{2}$ TPD profiles and attribution of peaks to different types of adsorbed $\mathrm{SO}_{2}$, bound to $\mathrm{Ag}$ and alumina. The catalyst regeneration temperature was lower than any of the $\mathrm{SO}_{2}$ desorption peaks, observed in the study, which did not allow drawing a clear conclusion about the deactivation and regeneration mechanisms.

Breen with coworkers [9] also demontrated a drastic dependence of the catalyst degree of poisoning on the temperature of $\mathrm{NO}_{\mathrm{x}} \mathrm{SCR}$ by octane and toluene. The following was observed; at low temperatures $\left(<235^{\circ} \mathrm{C}\right)$ little deactivation, between 235 and $500{ }^{\circ} \mathrm{C}-$ severe deactivation and at $\mathrm{T}>590{ }^{\circ} \mathrm{C}$ - activation due to a suppression of unselective oxidation of hydrocarbons. The low temperature sulfur tolerance was ascribed to low catalyst activity in $\mathrm{SO}_{2}$ oxidation to $\mathrm{SO}_{3}$ with the latter considered to be the main poisoning agent for $\mathrm{Ag} / \mathrm{Al}_{2} \mathrm{O}_{3}$. The authors have evaluated a few regeneration options of which heating to $650^{\circ} \mathrm{C}$ in hydrogen-containing lean mixture showed 
promising results rather than regeneration under oxidizing conditions without $\mathrm{H}_{2}$. The fastest regeneration technique included heating the catalyst a rich mixture containing $\mathrm{CO}$ and hydrogen.

The results of other research groups $[10,11]$ agree with Breen's results in $\mathrm{SO}_{2}$ oxidation to $\mathrm{SO}_{3}$ by $\mathrm{NO}_{2}$ being the major step in the sulfur poisoning of $\mathrm{Ag} / \mathrm{Al}_{2} \mathrm{O}_{3}$ catalysts. Partial regeneration of the catalyst was observed after heating to $600{ }^{\circ} \mathrm{C}$ in a hydrocarbon-containing feed.

In this work we have attempted to reveal the $\mathrm{Ag} / \mathrm{Al}_{2} \mathrm{O}_{3}$ sulfation and regeneration mechanisms, which will allow us to develop an efficient regeneration strategy for the ammonia SCR catalyst in question. Special attention was given to the catalyst operation below $300{ }^{\circ} \mathrm{C}$ for applications in light-duty diesel vehicles low temperatures are of great importance [10]. The suggested mechanism was supported by DFT calculations. The regeneration strategy using the high temperatures developed during Diesel Particulate Filter (DPF) regeneration in diesel cars was evaluated.

\section{Experimental}

\subsection{Catalyst preparation}

Parent $\gamma$-alumina (Puralox TH 100/150, $\mathrm{S}_{\mathrm{BET}}=150 \mathrm{~m}^{2} / \mathrm{g}$ ) was kindly provided by SASOL. 1-3 wt.\% Ag/ $\mathrm{Al}_{2} \mathrm{O}_{3}$ were obtained by incipient wetness impregnation of parent $\gamma$-alumina by $\mathrm{AgNO}_{3}$ (Sigma-Aldrich) dissolved in deionized water. After impregnation the catalyst was dried at room temperature overnight and calcined at $550{ }^{\circ} \mathrm{C}$ for 4 hours in static air. The calcined catalyst was tableted, crushed and sieved to obtain a $0.18-$ $0.35 \mathrm{~mm}$ fraction (mesh $80-$ mesh 45 ) used in the catalytic tests. A new batch of catalyst was sulfated and used to test every new regeneration recipe. 


\subsection{Determination of the specific surface area}

The specific surface areas $\left(\mathrm{S}_{\mathrm{BET}}\right)$ of the catalysts were measured by $\mathrm{N}_{2}$-adsorption with a Micromeritics Gemini instrument. Untreated catalysts were measured in powder form and for the catalysts after testing a $0.18-0.35 \mathrm{~mm}$ fraction of particles (as in catalytic tests) was used for the BET measurement.

\subsection{Catalysis}

Temperature-programmed activity tests were carried out in a fixed-bed flow reactor (quartz tube with $4 \mathrm{~mm}$ inner diameter) in a temperature programmed mode while the temperature was decreased from $400{ }^{\circ} \mathrm{C}$ to $150{ }^{\circ} \mathrm{C}$ with a rate of $2{ }^{\circ} \mathrm{C} / \mathrm{min}$. Prior to the temperature ramp the catalyst was heated to $470{ }^{\circ} \mathrm{C}$ for $30 \mathrm{~min}$. in the gas mixture used for the tests. The temperature was controlled using a Eurotherm 2408 temperature controller with a K-type thermocouple. $45 \mathrm{mg}$ of catalyst was diluted with $100 \mathrm{mg}$ of $\mathrm{SiC}$ (mesh 60 ) and placed on a quartz wool bed. The bed height was $\sim 11 \mathrm{~mm}$ and the GHSV, calculated using the volume of the pure catalyst was $\sim 110000 \mathrm{~h}^{-1}$. The gas composition normally contained 500 ppm NO, 520 ppm $\mathrm{NH}_{3}, 1200$ ppm of $\mathrm{H}_{2}, 8.3 \%$ $\mathrm{O}_{2}$, and 7\% water balanced with Ar. For sulfur poisoning tests $10 \mathrm{ppm} \mathrm{SO}_{2}$ was admixed to the feed. Water was dosed by an ISCO 100DM syringe pump through a heated capillary. Reaction products were analyzed by a Thermo Fisher Nicolet 6700 FTIR analyzer, equipped with a $2 \mathrm{~m}$ gas cell. Gas capillaries were heated to $\sim 130{ }^{\circ} \mathrm{C}$ and the FTIR gas cell to $165^{\circ} \mathrm{C}$ to avoid condensation of water and formation of ammonium nitrate.

Conversions were calculated using the following equations: 


$$
\begin{gathered}
X_{N O x}=1-\frac{C_{N O x}^{\text {outlet }}}{C_{N O x}^{\text {inlet }}}, \\
\text { and } X_{N_{3}}=1-\frac{C_{N H_{3}}^{\text {outlet }}}{C_{N_{3}}^{\text {inlet }}},
\end{gathered}
$$

where $X_{N O x}$ denotes the conversion of $\mathrm{NO}_{\mathrm{x}}$ to $\mathrm{N}_{2}$ and $C_{N O x}{ }^{\text {inlet }}$ and $C_{N O x}{ }^{\text {outlet }}$ is the $\mathrm{NO}_{\mathrm{x}}$ concentrations at the inlet and outlet of the reactor respectively, where:

$$
C_{\mathrm{NOx}}=C_{\mathrm{NO}}+C_{\mathrm{NO}_{2}}+C_{\mathrm{N}_{2} \mathrm{O}}
$$

\subsection{DFT calculations}

The plane wave density functional theory (DFT) code DACAPO was used to calculate the adsorption energies and the gas phase energies of the adsorbates [12]. A plane wave cutoff of $340.15 \mathrm{eV}$ and a density cutoff of $680 \mathrm{eV}$ was used in the calculations. The core electrons were described by Vanderbilt ultrasoft pseudopotentials. The RBPE functional was used for describing the exchange correlation energy [13].

The adsorption energies of the $\mathrm{SO}_{2}, \mathrm{SO}_{3}$, and $\mathrm{SO}_{4}$ species were studied over the $\mathrm{Ag}$ (111) terrace and (211) step surfaces, on a $\gamma-\mathrm{Al}_{2} \mathrm{O}_{3}$ model step surface, and two single Ag sites constructed by replacing one $\mathrm{Al}$ atom for $\mathrm{Ag}$ in the alumina step surface and by attaching one $\mathrm{Ag}$ atom to the $\gamma-\mathrm{Al}_{2} \mathrm{O}_{3}$ step (see supplementary material for the geometries).

For the Ag (111) and (211) surfaces, we used a $4 \times 4 \times 1$ Monkhorst-Pack k-point sampling in the irreducible Brillouin zone. We employed a $3 \times 3$ surface cell for the $\mathrm{Ag}$ (111) and $3 \times 1$ surface cell for the Ag (211) surfaces. For the (111) surface we used a four-layer slab where the two top-most layers were allowed to relax, whereas for the 
(211) surfaces we used a slab model with nine layers and the topmost three layers are allowed to relax. In all the model calculations, neighboring slabs were separated by more than $10 \AA$ of vacuum.

For the calculation of $\gamma-\mathrm{Al}_{2} \mathrm{O}_{3}$ and the adsorption of different species on $\gamma-\mathrm{Al}_{2} \mathrm{O}_{3}$ we also used the DACAPO code with a plane wave cutoff of $340.15 \mathrm{eV}$ and a density cutoff of $680 \mathrm{eV}$. A $4 \times 4 \times 1$ Monkhorst-Pack k-point sampling in the irreducible Brillouin zone was used for $\gamma-\mathrm{Al}_{2} \mathrm{O}_{3}$. The $\gamma-\mathrm{Al}_{2} \mathrm{O}_{3}$ surface was modeled by a step on a nonspinel $\gamma-\mathrm{Al}_{2} \mathrm{O}_{3}$ structure which was derived from bulk $\gamma-\mathrm{Al}_{2} \mathrm{O}_{3}$ model in [14]. The cell parameters for the $\gamma-\mathrm{Al}_{2} \mathrm{O}_{3}$ model step surface are $\mathrm{a}=8.0680 \AA$ and $\mathrm{b}=10.0092 \AA$ and $\alpha=\beta=\gamma=90^{\circ}$. For the $\gamma-\mathrm{Al}_{2} \mathrm{O}_{3}$ surface the bottom two layers were fixed whereas the top-most three layers were allowed to relax. In all the model $\gamma-\mathrm{Al}_{2} \mathrm{O}_{3}$ surfaces, the neighboring slabs are separated by more than $10 \AA$ of vacuum.

$\mathrm{SO}_{\mathrm{x}}$ adsorption energies were calculated relative to gas phase energies of $\mathrm{SO}_{2}(\mathrm{~g})+$ $\mathrm{O}_{2}(\mathrm{~g})$

In the case of the $\mathrm{Ag}$ (111) and $\mathrm{Ag}$ (211) surfaces desorption of $\mathrm{SO}_{4}$ as the most stable species was considered as $\mathrm{SO}_{2}(\mathrm{~g})+\mathrm{O}_{2}(\mathrm{~g})$. For calculation of desorption temperatures for $\mathrm{SO}_{2}$ and $\mathrm{SO}_{3}$ we used the following procedure. Starting from the chemical equation:

$$
\begin{aligned}
& \mathrm{SO}_{2}+* \leftrightarrow \mathrm{SO}_{2} * \\
& \mathrm{SO}_{2}+1 / 2 \mathrm{O}_{2}+* \leftrightarrow \mathrm{SO}_{3} *
\end{aligned}
$$

where $*$ is the free surface site and $\mathrm{SO}_{\mathrm{x}} *$ is the adsorbed species. We can write down the ratio of occupied and free adsorption sites:

$$
\frac{\theta_{S O x}}{\theta^{*}}=K_{a d s} \cdot P_{S O x}=\exp \left(-\frac{\Delta G_{a d s}}{k T}\right) \cdot P_{S O x}=\exp \left(\frac{-\left(\Delta G_{a d s}^{\Theta}-k T \ln P_{S O x}\right)}{k T}\right)
$$


that at the desorption temperature the numbers of occupied and free adsorption sites will equal $\left(\Theta_{\mathrm{SOx}}=\Theta^{*}\right)$, which gives:

$$
\begin{aligned}
& \Delta G_{a d s}^{\Theta}-k T \ln P_{S O x}=0, \text { or } \\
& \Delta E_{a d s}-\Delta Z P E_{a d s}-T \cdot \Delta S_{a d s}-k T \ln P_{S O x}=0,
\end{aligned}
$$

We calculate the ZPE (zero point energy) and the entropy of the $\mathrm{SO}_{\mathrm{x}}$ in their adsorbed state and so it is possible to calculate the desorption temperature for a given partial pressure of $\mathrm{SO}_{\mathrm{x}}$ :

$$
T=\frac{\Delta E_{a d s}}{k \ln P_{S O x}-\Delta S_{g a s}}
$$

The $\mathrm{SO}_{\mathrm{x}}$ entropy and ZPE found for $\gamma-\mathrm{Al}_{2} \mathrm{O}_{3}$ model surface were used for the single $\mathrm{Ag}$ atom sites on the $\gamma-\mathrm{Al}_{2} \mathrm{O}_{3}$. Standard entropy values for $\mathrm{SO}_{2}$ and $\mathrm{SO}_{3}$ from [15] (neglecting entropy change with temperature) and a partial pressure of $\mathrm{SO}_{\mathrm{x}} 4 \cdot 10^{-7} \mathrm{bar}$ (0.4 ppm in [9]) and partial pressure of $\mathrm{O}_{2}$ is 0.07 bar [9] were used in the calculations.

\section{Results and discussion}

\subsection{Catalyst choice: stability of $\mathrm{Ag}_{\mathrm{Al}} \mathrm{I}_{2} \mathrm{O}_{3}$ and options for the regeneration}

\subsubsection{The catalyst choice}

Temperature dependence of $\mathrm{NO}_{\mathrm{x}}$ and $\mathrm{NH}_{3}$ conversions for the fresh 1-3\% $\mathrm{Ag} / \mathrm{Al}_{2} \mathrm{O}_{3}$ catalysts is shown on figures $1 \mathrm{a}$ and $1 \mathrm{~b}$ respectively. $1 \% \mathrm{Ag} / \mathrm{Al}_{2} \mathrm{O}_{3}$ exhibits SCR onset at $130{ }^{\circ} \mathrm{C}$ reaching $80 \% \mathrm{NO}_{\mathrm{x}}$ conversion at $200{ }^{\circ} \mathrm{C}$ and leveling $\mathrm{NO}_{\mathrm{x}}$ conversion at $90 \%$ at $\mathrm{T}>300{ }^{\circ} \mathrm{C}$. This is in agreement with previous studies [2]. $2 \%$ and $3 \% \mathrm{Ag} / \mathrm{Al}_{2} \mathrm{O}_{3}$ catalysts demonstrate SCR onset shifted by $7{ }^{\circ} \mathrm{C}$ to lower temperatures compared $1 \%$, but lower maximum conversion and generally lower SCR activity at higher temperatures, unlike results of Shimizu and Satsuma [3]. The $\mathrm{NH}_{3}$ conversion follow 
the $\mathrm{NO}_{\mathrm{x}}$ conversion at $\mathrm{T}<270-300{ }^{\circ} \mathrm{C}$. At higher temperature $\mathrm{NH}_{3}$ becomes oxidized and the $\mathrm{NH}_{3}$ conversion is higher than $\mathrm{NO}_{\mathrm{x}}$ conversion. Thus, $\mathrm{NH}_{3}$ oxidation plays some role in the decrease of high temperature $\mathrm{NO}_{\mathrm{x}}$ conversion but this is not the main reason. The reason for observing conversion maxima for $2 \%$ and $3 \% \mathrm{Ag} / \mathrm{Al}_{2} \mathrm{O}_{3}$ catalysts at $200{ }^{\circ} \mathrm{C}$ with subsequent drop in $\mathrm{NH}_{3}$ and $\mathrm{NO}_{\mathrm{x}}$ conversions could be direct oxidation of $\mathrm{H}_{2}$ by oxygen taking over. As it was shown earlier no $\mathrm{NO}$ and $\mathrm{NH}_{3}$ is converted over an $\mathrm{Ag} / \mathrm{Al}_{2} \mathrm{O}_{3}$ catalyst in the absence of $\mathrm{H}_{2}$ [16]. Another possible reason is the lack of strong acid sites for $\mathrm{NH}_{3}$ adsorption in the $2-3 \% \mathrm{Ag} / \mathrm{Al}_{2} \mathrm{O}_{3}$ catalysts which is demonstrated in [17].

Noteworthy, the tested catalysts demonstrate very high stability at temperature up to $700{ }^{\circ} \mathrm{C}$ which has also been shown in the number of papers on HC-SCR $[3,9]$. To further check the thermal stability of the $1 \% \mathrm{Ag} / \mathrm{Al}_{2} \mathrm{O}_{3}$ catalyst it was subjected to hydrothermal deactivation at $750{ }^{\circ} \mathrm{C}$ for 16 hours. The activity of the obtained catalyst is reported in figs. $1 \mathrm{a}$ and $1 \mathrm{~b}$ as gray dotted lines. The low-temperature conversion is only slightly shifted by $3{ }^{\circ} \mathrm{C}$, whereas at $\mathrm{T}>300{ }^{\circ} \mathrm{C}$ one may observe a decrease in $\mathrm{NO}_{\mathrm{x}}$ and $\mathrm{NH}_{3}$ conversions similar to that observed for catalysts with higher $\mathrm{Ag}$ loading. This may indicate sintering of $\mathrm{Ag}$ particles leading to the increased unselective oxidation of hydrogen. At the same time, the relatively small decrease of the catalyst specific surface area $\left(\mathrm{S}_{\mathrm{BET}}\right)$ does not indicate any significant change in the alumina support (table 1).

Contrary to the hydrothermal aging, sulfur poisoning of $\mathrm{Ag} / \mathrm{Al}_{2} \mathrm{O}_{3}$ leads to significant catalyst deactivation. Preliminary experiments on the choice of sulfur poisoning temperature showed no catalyst deactivation with $\mathrm{SO}_{2}$ in the feed at $500{ }^{\circ} \mathrm{C}$ and the most severe deactivation in the temperature range $200-300{ }^{\circ} \mathrm{C}$ in very good agreement with the earlier reported results for HC-SCR [8, 9]. Therefore, preliminary 
$\mathrm{SO}_{2}$ deactivation studies of $1-3 \% \mathrm{Ag} / \mathrm{Al}_{2} \mathrm{O}_{3}$ were performed at $200-227{ }^{\circ} \mathrm{C}$ and all the following deactivation-regeneration studies of $2 \% \mathrm{Ag} / \mathrm{Al}_{2} \mathrm{O}_{3}$ were done at $250{ }^{\circ} \mathrm{C}$ (Fig. 1c). For the comparison of regeneration methods the $\mathrm{SO}_{2}$ poisoning was obtained by introducing $10 \mathrm{ppm} \mathrm{SO}_{2}$ to the SCR feed for 4 hours.

Catalytic performance of $1-3 \% \mathrm{Ag} / \mathrm{Al}_{2} \mathrm{O}_{3}$ in $\mathrm{NO}_{\mathrm{x}} \mathrm{SCR}$ after such sulfur treatment at $200-227^{\circ} \mathrm{C}$ is shown on fig. $1 \mathrm{~d}$. Lowering deactivation temperature from $250{ }^{\circ} \mathrm{C}$ to 200 ${ }^{\circ} \mathrm{C}$ leads to a very small shift of the low-temperature activity within $5{ }^{\circ} \mathrm{C}$, therefore, the temperature difference is not the determining factor for the observed activity difference. $1 \% \mathrm{Ag} / \mathrm{Al}_{2} \mathrm{O}_{3}$ was poisoned to the highest degree, whereas higher $\mathrm{Ag}$ loading led to better sulfur tolerance with $3 \% \mathrm{Ag} / \mathrm{Al}_{2} \mathrm{O}_{3}$ showing the highest $\mathrm{NO}_{\mathrm{x}}$ conversion at $\mathrm{T}<300$ ${ }^{\circ} \mathrm{C}$. It should be noted that after exposure to $\mathrm{SO}_{2}$ (and even after regeneration of $1 \%$ and $2 \% \mathrm{Ag} / \mathrm{Al}_{2} \mathrm{O}_{3}$ catalysts at $670{ }^{\circ} \mathrm{C}$ ) the $\mathrm{NH}_{3}$ conversion profiles coincided with the $\mathrm{NO}_{\mathrm{x}}$ conversion profiles for all tested samples. That indicates quenching of $\mathrm{NH}_{3}$ unselective oxidation over $1-3 \% \mathrm{Ag} / \mathrm{Al}_{2} \mathrm{O}_{3}$ by $\mathrm{SO}_{2}$. Due to the similarity of $\mathrm{NO}_{\mathrm{x}}$ and $\mathrm{NH}_{3}$ conversion curves for the sulfated catalysts only $\mathrm{NO}_{\mathrm{x}}$ conversions will be reported throughout the article.

Sulfation of 2 and $3 \% \mathrm{Ag} / \mathrm{Al}_{2} \mathrm{O}_{3}$ leads not only to a shift of the maximum $\mathrm{NO}_{\mathrm{x}}$ conversion to higher temperatures but also to an increase to significantly higher values than demonstrated over the fresh catalysts. The shift of the maximum activity of $2 \% \mathrm{Ag} / \mathrm{Al}_{2} \mathrm{O}_{3}$ along with "activation" of the catalyst at $227^{\circ} \mathrm{C}$ (near the conversion maximum of the fresh catalyst) and at $250{ }^{\circ} \mathrm{C}$ can be seen in Fig. 1c. Higher $\mathrm{SO}_{2}$ exposure leads to a shift of the maximum $\mathrm{NO}_{\mathrm{x}}$ conversion to higher temperatures along with deterioration of the low-temperature activity. The activity gain induced by sulfation has been observed earlier and attributed to the redistribution of Ag species [4]. 
However, as we have observed the decrease of unselective $\mathrm{NH}_{3}$ oxidation after $\mathrm{SO}_{2}$ exposure, we suppose the $\mathrm{SO}_{\mathrm{x}}$ blocking of sites active in $\mathrm{NH}_{3}$ and $\mathrm{H}_{2}$ oxidation to play a major role in the increased $\mathrm{NO}_{\mathrm{x}}$ conversion over 2 and $3 \% \mathrm{Ag} / \mathrm{Al}_{2} \mathrm{O}_{3}$ catalysts. At the same time $\mathrm{SO}_{2}$ adsorption increases the alumina acidity which can also play the role for the SCR activity as discussed in a separate publication [17].

Several options for the catalyst regeneration under hydrocarbon (HC) SCR have been suggested in the literature. All of them include heating sulfated $A g / \mathrm{Al}_{2} \mathrm{O}_{3}$ in different media - oxidizing [9], hydrogen (or hydrocarbon)-containing lean exhaust [6, $8,9,10]$ or rich exhaust $[6,9]$.

Heating sulfated $2 \% \mathrm{Ag} / \mathrm{Al}_{2} \mathrm{O}_{3}$ to $670{ }^{\circ} \mathrm{C}$ for $10 \mathrm{~min}$ in the $\mathrm{NO}_{\mathrm{x}} \mathrm{SCR}$ feed without hydrogen leads only to a small $10{ }^{\circ} \mathrm{C}$ shift of T50\% to lower temperatures (not shown). Therefore, regeneration of $\mathrm{Ag} / \mathrm{Al}_{2} \mathrm{O}_{3}$ for $\mathrm{NO}_{\mathrm{x}} \mathrm{SCR}$ by $\mathrm{NH}_{3}$ without co-feeding hydrogen is ineffective. Thus, regeneration at $670{ }^{\circ} \mathrm{C}$ in the reaction gas mixture was used to test the regeneration capability of $1-3 \% \mathrm{Ag} / \mathrm{Al}_{2} \mathrm{O}_{3}$ catalysts. Activity of the catalysts regenerated during $40 \mathrm{~min}$. is reported in fig. 1e. All catalysts partially regained the low-temperature activity, however, the high-temperature activity of $3 \% \mathrm{Ag} / \mathrm{Al}_{2} \mathrm{O}_{3}$ was decreased compared to the sulfated catalyst. At the same point this catalyst demonstrated a higher conversion of $\mathrm{NH}_{3}$ compared to $\mathrm{NO}_{\mathrm{x}}$ at $\mathrm{T}>350{ }^{\circ} \mathrm{C}$, indicating $\mathrm{NH}_{3}$ oxidation. $2 \% \mathrm{Ag} / \mathrm{Al}_{2} \mathrm{O}_{3}$ showed the highest $\mathrm{NO}_{\mathrm{x}}$ conversion throughout the whole temperature region and will therefore, be used for the further study. For the simplicity in the text below and the following figures $2 \% \mathrm{Ag} / \mathrm{Al}_{2} \mathrm{O}_{3}$ will be referred as $\mathrm{Ag} / \mathrm{Al}_{2} \mathrm{O}_{3}$.

\subsubsection{Regeneration options}


To simulate regeneration in rich exhaust the catalyst was heated to $670{ }^{\circ} \mathrm{C}$ for $1 \mathrm{~min}$. with oxygen removed from the feed. The activity following from this rich regeneration is presented on fig. $2 \mathrm{a}$ as a solid line. The profile is significantly shifted to lower temperatures compared to the non-regenerated sample. Another feature is the maximum $\mathrm{NO}_{\mathrm{x}}$ conversion (96\%), which is now higher than that of both the fresh and the nonregenerated catalysts. Still, regeneration under rich conditions did not allow to regain the low-temperature activity completely.

However, obtaining rich exhaust from diesel engine leads to high fuel consumption and is, therefore, undesirable. Thus, we have preferred relatively fast catalyst regeneration under lean conditions with co-feeding hydrogen. The $\mathrm{NO}_{\mathrm{x}}$ conversion profile for $\mathrm{Ag} / \mathrm{Al}_{2} \mathrm{O}_{3}$ regenerated 10 min. at $670{ }^{\circ} \mathrm{C}$ in the standard $\mathrm{NO}_{\mathrm{x}} \mathrm{SCR}$ feed (with hydrogen) is shown on fig. $2 \mathrm{a}$ as a dashed line. The catalyst shows the same activity below $200{ }^{\circ} \mathrm{C}$ as when regenerated under rich conditions and at higher temperatures even higher conversion (up to $100 \%$ ). At the same time the surface area of the catalyst regenerated for 10 minutes is not deteriorated compared to the fresh catalyst (table 1). This kind of regeneration is very easy to implement in diesel vehicles because it can coincide with regeneration of the DPF, which requires a similar heating strategy.

\subsection{Influence of the regeneration time on the catalyst activity}

Regeneration time is of high importance for automotive catalysts, as heating the catalyst requires a lot of energy, i.e. fuel to be spent. Influence of the regeneration time (for regeneration under lean conditions with co-feeding hydrogen) on the activity of the regenerated catalyst is shown in fig. $2 \mathrm{~b}$. The value on the $\mathrm{Y}$-axis is the shift of 
temperature for $50 \% \mathrm{NO}_{\mathrm{x}}$ conversion over the regenerated catalyst relative to the fresh catalyst :

$$
\mathrm{T} 50 \% \text { shift }=\mathrm{T} 50 \%^{\text {regenerated }}-\mathrm{T} 50 \% \text { fresh }
$$

Zero at the timescale stands for non-regenerated catalyst. Heating to $670{ }^{\circ} \mathrm{C}$ for 1 min. leads to the shift of $\mathrm{T} 50 \%$ by $24{ }^{\circ} \mathrm{C}$ towards lower temperatures, which is already very good. Heating for $10 \mathrm{~min}$. allows us to get $6{ }^{\circ} \mathrm{C}$ lower T $50 \%$, but further treatment at high temperatures does not lead to significant further activation of the catalyst. The best $\mathrm{T} 50 \%$, we could get by regenerating $\mathrm{Ag} / \mathrm{Al}_{2} \mathrm{O}_{3}$, is $15{ }^{\circ} \mathrm{C}$ higher than $\mathrm{T} 50 \%$ of the fresh $\mathrm{Ag} / \mathrm{Al}_{2} \mathrm{O}_{3}$. That result is obtained after $40 \mathrm{~min}$ of regeneration. Higher regeneration time does not yield better activity but causes loss of the catalyst surface area (table 1) and is, therefore, undesirable. It is worth noting that we were not able to match the low-temperature activity of the fresh catalyst after regeneration.

\subsection{Developing a deactivation - regeneration strategy to mimic automotive catalyst} operating conditions

Typical lifecycle of an automotive light-duty $\mathrm{Ag} / \mathrm{Al}{ }_{2} \mathrm{O}_{3} \mathrm{NO}_{\mathrm{x}} \mathrm{SCR}$ catalyst comprises normal driving, during which the catalyst operates at low temperatures $150-350{ }^{\circ} \mathrm{C}$ [10] and is poisoned by sulfur, and regeneration which optimally coincides with regeneration of the DPF. To be more precise, useful vehicle running time according to

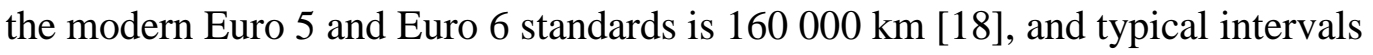
between DPF regenerations are 300 to $900 \mathrm{~km}$ (with the modern Volvo D5 light-duty diesel engine as an example ) [19], which gives a minimum of 160 catalyst regeneration cycles. Using average fuel consumption of this engine during urban driving (6.7 1/100 $\mathrm{km}$ with a manual gearbox), an average diesel fuel density approx. $850 \mathrm{~g} / \mathrm{l}$ [20], and a 
maximum allowed sulfur content of $10 \mathrm{ppm}$ in the diesel fuel [21], the total sulfur passed through the catalyst will amount to $91 \mathrm{~g}$ or $2.85 \mathrm{~mol}$. Using available data on the volume of monolith catalyst for the mentioned engine (9 liters) and the monolith density $2.5 \mathrm{~g} / \mathrm{in}^{3}[10]$, the weight of the washcoat for an automotive catalyst (15\% of the total) and the relative weight of the powder catalyst in the washcoat (80\%) [22] we get a total of $0.47 \mathrm{~g}$ ( $14.7 \mathrm{mmol})$ sulfur per gram of powder catalyst during the vehicle lifetime. Therefore, the amount of sulfur per one deactivation cycle will be $83 \mu \mathrm{mol}$ per gram of catalyst, assuming adsorption of all sulfur. In reality, however, not all sulfur will be adsorbed partly due to very high or low temperatures [9].

In our tests we have chosen the scheme involving catalyst poisoning with $10 \mathrm{ppm}$ $\mathrm{SO}_{2}$ at intermediate temperature of $250{ }^{\circ} \mathrm{C}$ for 1 hour which gives us a sulfur exposure before regeneration of $65 \mu \mathrm{mol}$ per gram of catalyst, which is close to the theoretical maximum value calculated above. Thus, we will use this protocol as "worst case" scenario.

Figs. 3a and Figs. 3b show two different ways of testing sulfur tolerance with the same total sulfur exposure (4 hours with $10 \mathrm{ppm} \mathrm{SO}_{2}$, corresponds to $260 \mu \mathrm{mol} / \mathrm{g}$ catalyst) and the same regeneration time, but split by four relatively small regeneration segments in the second case.

The comparison of the catalyst activity after these two tests is given on fig. 3c. Evidently, the low-temperature activities of the two poisoned catalysts are identical. The data in Figs. $3 \mathrm{a}$ and $3 \mathrm{~b}$ does not allow us to state that the regenerated catalyst activity observed in fig. 3c represents "steady state" automotive catalyst activity in both cases. Further testing is needed to reveal "steady state" catalyst activity during sulfation regeneration cycles. 


\subsection{Cycling deactivation - regeneration}

In order to clarify if the catalyst will be further deactivated after many $1 \mathrm{~h} . \mathrm{SO}_{2}$ poisoning - $10 \mathrm{~min}$. regeneration cycles we have carried out 30 deactivation (at $250{ }^{\circ} \mathrm{C}$ ) - regeneration (at $670{ }^{\circ} \mathrm{C}$ ) cycles. Evolution of the $\mathrm{NO}_{\mathrm{x}}$ and $\mathrm{NH}_{3}$ conversions during the first 9 cycles of the experiment is shown in fig. 4 .

During the sulfation of the fresh catalyst (first $60 \mathrm{~min}$.) $\mathrm{NO}_{\mathrm{x}}$ conversion steadily increases. During heating the catalyst to $670{ }^{\circ} \mathrm{C}$ the $\mathrm{NO}_{\mathrm{x}}$ conversion drops to slightly negative values. According to eq. (1) in the section 2.3 this is due to a higher $\mathrm{NO}_{\mathrm{x}}$ concentration at the reactor outlet than at the inlet. The latter is caused by oxidation of part of ammonia to $\mathrm{NO}_{\mathrm{x}}$ at the regeneration temperature which can be seen by the higher conversion of $\mathrm{NH}_{3}$ compared to $\mathrm{NO}_{\mathrm{x}}$ at $\mathrm{T}>500{ }^{\circ} \mathrm{C}$. To prevent ammonia oxidation in the real life application it is possible to switch off ammonia supply during regeneration without compromising regeneration efficiency.

The $\mathrm{NO}_{\mathrm{x}}$ conversion following regeneration is maximal (97\%) after the first regeneration and decreases only a little (to 95\%) with further regeneration cycles. However, sulfur poisoning of the regenerated sample leads to a decrease in the $\mathrm{NO}_{\mathrm{x}}$ conversion at the end of each of the first deactivation cycles. This decrease in $\mathrm{NO}_{\mathrm{x}}$ conversion could indicate that during each of these first regenerations the $\mathrm{SO}_{\mathrm{x}}$ adsorbed during the preceding deactivation cycle is not completely removed from the catalyst surface. After seven sulfation-regeneration cycles $\mathrm{NO}_{\mathrm{x}}$ conversion is stabilized, so each new testing cycle yields the same profile as the previous. Thus, further sulfation and regeneration do not change the catalyst performance. 
Integration of the $\mathrm{SO}_{2}$ signal measured by FTIR during $10^{\text {th }}-20^{\text {th }}$ cycles (they are all equal) gives the amount of $\mathrm{SO}_{2}$ equal to the amount of $\mathrm{SO}_{2}$ passed through the catalyst during these cycles. Therefore, using FTIR data we can estimate the amount of $\mathrm{SO}_{2}$, which was accumulated in the catalyst and not desorbed during the first regenerations to be $0.11 \mathrm{mmol}$ per gram catalyst.

Our data (not shown) suggests that the $\mathrm{SO}_{2}$ poisoning effect is cumulative in the range of $\mathrm{SO}_{2}$ concentrations $0.5-10 \mathrm{ppm}$, i.e. the catalyst deactivation degree depends only on total $\mathrm{SO}_{2}$ exposure. Therefore, with the same $\mathrm{SO}_{\mathrm{x}}$ exposure between DPF regenerations as in this study real catalyst performance will be high enough even in the end of a sulfation cycle before the next regeneration.

\subsection{Mechanism of $\mathrm{Ag} / \mathrm{Al}_{2} \mathrm{O}_{3}$ sulfation and regeneration}

The results obtained in the previous section 3.4. set the ground for a few conclusions regarding the sulfation and regeneration mechanisms for $\mathrm{Ag} / \mathrm{Al}_{2} \mathrm{O}_{3}$ catalysts of hydrogen-assisted $\mathrm{NO}_{x} \mathrm{SCR}$ by $\mathrm{NH}_{3}$.

First of all, some amount of $\mathrm{SO}_{\mathrm{x}}$ is not desorbed after regeneration. This amount was estimated in the previous section and is reproducible. At the same time we cannot regenerate the full low-temperature activity of $\mathrm{Ag} / \mathrm{Al}_{2} \mathrm{O}_{3}$, no matter if lean hydrogencontaining or rich mixtures were used for the regeneration. The SCR reaction onset for the sulfated and regenerated catalyst is always shifted to higher temperatures. Therefore, we suppose that a certain type of active sites exists (name it "Type I"), which stand for $\mathrm{Ag} / \mathrm{Al}_{2} \mathrm{O}_{3}$ activity at low temperatures $\left(<200{ }^{\circ} \mathrm{C}\right)$, that are irreversibly poisoned by $\mathrm{SO}_{2}$ and can not be regenerated using standard techniques. Taking into account the very low 
sulfur tolerance of low-loaded $\mathrm{Ag} / \mathrm{Al}_{2} \mathrm{O}_{3}[6,7]$, we can attribute Type I active sites to highly dispersed silver e.g. $\mathrm{Ag}^{\delta+}$ atoms or $\mathrm{Ag}^{+}$ions [23, 24] (see Fig. 5).

$\mathrm{SO}_{\mathrm{x}}$ adsorption on the alumina surface (where dispersed silver is localized) blocks these type I active sites. $\mathrm{SO}_{\mathrm{x}}$ can be adsorbed on single-atom $\mathrm{Ag}$ sites on the alumina as well as on the neighboring $\mathrm{Al}$ atoms. It is impossible to desorb $\mathrm{SO}_{\mathrm{x}}$ from the alumina surface by heating the catalyst to $670{ }^{\circ} \mathrm{C}[25]$ and, therefore, Type I active sites could not be regenerated.

Another evidence of irreversibly poisoned active sites is the formation of excess of nitrogen dioxide over the fresh catalyst (fig. 6b, solid line), a catalytic function which is irreversibly poisoned by $\mathrm{SO}_{2}$ and cannot be regenerated (fig. $6 \mathrm{~b}$, dotted line). Therefore, we also attribute the increased NO oxidation capacity to Type I active sites.

However, the possibility of regeneration of the most of the SCR activity of $\mathrm{Ag} / \mathrm{Al}_{2} \mathrm{O}_{3}$ hints on the existence of "Type II" active sites. As they are more abundant in more $\mathrm{SO}_{2}$ tolerant high-loaded $\mathrm{Ag} / \mathrm{Al}_{2} \mathrm{O}_{3}[7]$ we attribute them to the surface of $\mathrm{Ag}$ nanoparticles. It has been shown that it is possible to desorb $\mathrm{SO}_{2}$ from the $\mathrm{Ag}$ surface at temperatures near $600{ }^{\circ} \mathrm{C}$ [25]. Thus, we assume that sulfation and regeneration of these Type II active sites determines the SCR activity of $\mathrm{Ag} / \mathrm{Al}_{2} \mathrm{O}_{3}$ with sulfur-containing fuel in diesel vehicles. According to the SCR mechanism suggested in [16] these type II species are also capable of oxidizing $\mathrm{NO}$ to $\mathrm{NO}_{2}$ which further reacts with $\mathrm{NH}_{3}$ over alumina. However, type II sites are less active which leads to the deficit of $\mathrm{NO}_{2}$ and prevents observing it in the gas phase when $\mathrm{NH}_{3}$ is present.

Our assumption about the existence and function of Type I active sites can be verified by the following. As follows from the $\mathrm{SO}_{2} \mathrm{TPD}$ profiles in $[11,25]$ it is possible to desorb $\mathrm{SO}_{\mathrm{x}}$ from alumina surface at ca. $1000{ }^{\circ} \mathrm{C}$. Of course, the alumina will 
undergo partial restructuring at this temperature [26] accompanied by the formation of the $\alpha-\mathrm{Al}_{2} \mathrm{O}_{3}$ phase, which will partially ruin the catalyst. However, this may help to test the principle.

The results of heating of sulfated $\mathrm{Ag} / \mathrm{Al}_{2} \mathrm{O}_{3}$ to $950{ }^{\circ} \mathrm{C}$ in the $\mathrm{SCR}$ gas mixture with further immediate cooling are shown in figs. $6 \mathrm{a}$ and $6 \mathrm{~b}$ as dashed lines. By removing $\mathrm{SO}_{\mathrm{x}}$ from the alumina surface (observed by FTIR) we were able to regain SCR onset at the same temperature as for the fresh $\mathrm{Ag} / \mathrm{Al}_{2} \mathrm{O}_{3}$ (fig. 6a). At the same time we were able to regenerate excessive $\mathrm{NO}_{2}$ production (fig. 6b) which was impossible to get by any kind of regeneration at lower temperature. Still, the maximum activity of the catalyst was lower than that of the fresh catalyst resembling the activity of $3 \% \mathrm{Ag} / \mathrm{Al}_{2} \mathrm{O}_{3}$ (fig. 1a). The specific surface area of the catalyst regenerated at $950{ }^{\circ} \mathrm{C}$ did not change significantly compared to the fresh sample (table 1), therefore, it is rather sintering of Ag particles which caused a drop in the maximum activity. Thus, we consider possibility of regenerating low temperature activity as an evidence for the existence of several types of active sites in $\mathrm{Ag} / \mathrm{Al}_{2} \mathrm{O}_{3}$ as was previously stated for $\mathrm{HC}-\mathrm{SCR}$ $\mathrm{Ag} / \mathrm{Al}_{2} \mathrm{O}_{3}$ catalysts [27].

The fact that $\mathrm{SO}_{\mathrm{x}}$ irreversibly adsorbed on the alumina surface does not hinder that the SCR reaction can be explained if we assume that $\mathrm{Ag}$ species participate in the oxidation of $\mathrm{NO}$ to $\mathrm{NO}_{2}$ and the alumina facilitates further reaction of $\mathrm{NO}, \mathrm{NO}_{2}$ and $\mathrm{NH}_{3}$ according to the "Fast SCR" mechanism [28]. Since "Fast SCR" occurs over a number of acidic surfaces, sulfated alumina should catalyze $\mathrm{SCR}$ as well if $\mathrm{SO}_{\mathrm{x}}$-free $\mathrm{Ag}$ surface is left to oxidize NO. 


\subsection{Evaluation of the proposed sulfation and regeneration mechanism of $\mathrm{Ag}_{\mathrm{Al}} \mathrm{Al}_{2} \mathrm{O}_{3}$}

by $D F T$

Adsorption energies of $\mathrm{SO}_{2}, \mathrm{SO}_{3}$, and $\mathrm{SO}_{4}$ for the most energetically favorable adsorption geometries for different adsorption sites are summarized in the Table 2 and the corresponding geometries for the $\gamma$-alumina model step surface are shown in Fig. 7. It should be noted that $\mathrm{SO}_{\mathrm{x}}$ can be adsorbed on the $\gamma$-alumina in different configurations with similar energies and only the lowest energies (strongest adsorption) are shown. The DFT calculation shows that the $\mathrm{SO}_{\mathrm{x}}$ adsorbs strongly on the step sites which is expected from the low coordination of these sites and the steric freedom available at the step sites [29 - 31]. At the same time the surface step is representative of small 1-3 nm nanoparticles containing mostly undercoordinated surface atoms [32].

Two trends can be identified from these values. First global trend is that all types of $\mathrm{SO}_{\mathrm{x}}$ bind significantly stronger to the alumina surface than the metal surface. The adsorption sites also include single Ag sites at the alumina surface with Ag atom built in the surface substituting $\mathrm{Al}$ is binding $\mathrm{SO}_{\mathrm{x}}$ most strongly. This can be explained by a thermodinamically unfavorable defect structure of this site. Secondly, the oxidation of $\mathrm{SO}_{2}$ to $\mathrm{SO}_{3}$ is thermodynamically favorable, with subsequent poisoning of the catalyst surface by the resulting $\mathrm{SO}_{3}$. This has been suggested in [9] and probably involves reaction with $\mathrm{NO}_{2}$ [11]. $\mathrm{SO}_{2}$ alone cannot be adsorbed on the studied metallic $\mathrm{Ag}$ surfaces under reaction conditions and $\mathrm{SO}_{\mathrm{x}}$ can, thus, only poison the alumina support or single Ag sites on this surface.

The calculated desorption temperatures (table 2) are low but the order, at which regeneration of Type II (Ag surface) and Type I (highly dispersed Ag on the alumina) occurs is in agreement with the mechanism of $\mathrm{Ag} / \mathrm{Al}_{2} \mathrm{O}_{3}$ poisoning and regeneration 
suggested in the section 3.5. The difference between calculated and experimental desorption temperatures $[11,25]$ might indicate the formation of bulk silver sulfate $[7$, $33,34]$.

At the same time addition of hydrogen significantly enhances catalyst regeneration i.e. removal of $\mathrm{SO}_{\mathrm{x}}$ which could be due to the formation of the correspondent $\mathrm{HSO}_{\mathrm{x}}$ species with their subsequent desorption. Table 3 shows the energies of the $\mathrm{HSO}_{\mathrm{x}}$ species in the gas phase and adsorbed on the most energetically favorable sites. The corresponding adsorption energies are calculated as a difference between the energy in the adsorbed state and gas phase energy. According to the given numbers, the formation of $\mathrm{HSO}_{4}$ and $\mathrm{H}_{2} \mathrm{SO}_{4}$ species is highly favorable on all modeled adsorption sites and as the adsorption energies of $\mathrm{HSO}_{4}$ and $\mathrm{H}_{2} \mathrm{SO}_{4}$ with respect to $\mathrm{H}_{2} \mathrm{SO}_{4}(\mathrm{~g})$ is very small ($0.17 \mathrm{eV}$ for $\mathrm{HSO}_{4}$ desorbing as $\mathrm{H}_{2} \mathrm{SO}_{4}$ from $\mathrm{Ag}$ (211) and $-0.28 \mathrm{eV}$ for $\mathrm{H}_{2} \mathrm{SO}_{4}$ on the $\gamma$ $\mathrm{Al}_{2} \mathrm{O}_{3}$ step surface) it can be easily desorbed from the catalytic surface. Thus, presence of $\mathrm{H}_{2}$ may promote the desorption of $\mathrm{SO}_{\mathrm{x}}$ species from the catalyst surface via formation of $\mathrm{H}_{2} \mathrm{SO}_{4}(\mathrm{~g})$ in agreement with the experimental observations.

\section{Conclusions}

Sulfur tolerance and regeneration options of $2 \% \mathrm{Ag} / \gamma-\mathrm{Al}_{2} \mathrm{O}_{3}$ catalyst for $\mathrm{H}_{2}$-assisted $\mathrm{NO}_{\mathrm{x}} \mathrm{SCR}$ by $\mathrm{NH}_{3}$ have been tested. The catalyst has medium sulfur tolerance at low temperatures, however a good capability of regeneration. This regeneration should include heating to $650-700{ }^{\circ} \mathrm{C}$ for $10-20$ min., provided the SCR gas feed is unchanged (ammonia may be removed) and hydrogen is co-fed. Regeneration of $\mathrm{Ag} / \mathrm{Al}_{2} \mathrm{O}_{3}$ without oxygen (rich mixture) leads to essentially the same effect, but requires less time. 
Heating to $650-700{ }^{\circ} \mathrm{C}$ does not allow full regeneration of low-temperature activity and does not allow recovery of $\mathrm{NO}_{2}$ formation over $\mathrm{Ag} / \mathrm{Al}_{2} \mathrm{O}_{3}$ in the course of SCR.

During the long-term tests with cycling poisoning - regeneration periods catalyst activity is regenerated during each regeneration cycle, but at least for the first 6-7 cycles sulfur species are accumulated on the catalyst. Presumably, $\mathrm{SO}_{\mathrm{x}}$ is removed from $\mathrm{Ag}$, but not from the alumina surface during standard regeneration, which allows us to make a conclusion on the existence of different active sites in $\mathrm{Ag} / \mathrm{Al}_{2} \mathrm{O}_{3}$, namely finely dispersed Ag ions and Ag nanoparticles.

\section{Acknowledgements}

This work was supported by The Danish Council for Strategic Research through grant 09-067233. 


\section{References}

[1] T.V. Johnson, Int. J. Engine Res. 10 (2009) 275-285

[2] M. Richter, R. Fricke, and R. Eckelt, Catal. Lett. 94 (2004) 115-118

[3] K.-I. Shimizu and A. Satsuma, Appl. Catal. B 77 (2007) 202-205

[4] A. Abe, N. Aoyama, S. Sumiya, N. Kakuta, and K. Yoshida, Catal. Lett. 51(1998) 59

[5] H. Kannisto, X. Karatzas, J. Edvardsson, L.J. Pettersson, and H.H. Ingelsten, Appl. Catal. B 104 (2011) 74-83

[6] F.C. Meunier and J.R.H. Ross, Appl. Catal. B 24 (2000) 23-32

[7] P.W. Park and C.L. Boyer, Appl. Catal. B 59 (2005) 27-34

[8] S. Satokawa, K.-I. Yamaseki, and H. Uchida, Appl. Catal. B 34 (2001) 299-306

[9] J.P. Breen, R. Burch, C. Hardacre, C.J. Hill, B. Krutzsch, B. Bandl-Konrad, E. Jobson, L. Cider, P.G. Blakeman, L.J. Peace, M.V. Twigg, M. Preis, and M. Gottschling, Appl. Catal. B 70 (2007) 36-44

[10] F. Klingstedt, K. Eränen, L.-E. Lindfors, S. Andersson, L. Cider, C. Landberg, E. Jobson, L. Eriksson, T. Ilkenhans, and D. Webster, Top. Catal. 30/31 (2004) 2730

[11] Q. Ma, Y. Liu, and H. He, J. Phys. Chem. A 112 (2008) 6630-6635

[12] B. Hammer, L.B. Hansen, and J.K. Nørskov, Phys. Rev. B 59 (1999) 7413-7421

[13] E. Mènendez-Proupin and G. Gutièrrez, Phys. Rev. B 72 (2005) 35116-35119

[14] M. Digne, P. Sautet, P. Raybaud, P. Euzen, and H. Toulhoat, J. Catal., 226 (2004) 54-68

[15] Chase, M.W. Jr., NIST-JANAF Themochemical Tables, Fourth Edition, J. Phys. Chem. Ref. Data, Monograph 9, 1998, 1-1951

[16] D.E. Doronkin, S. Fogel, S. Tamm, L. Olsson, T.S. Khan, T. Bligaard, P. Gabrielsson, and S. Dahl, Appl. Catal. B 2011, Accepted Manuscript, doi: 10.1016/j.apcatb.2011.11.042 
[17] S. Fogel and D.E. Doronkin, et. al. Manuscript in preparation

[18] REGULATION (EC) No 715/2007 OF THE EUROPEAN PARLIAMENT AND OF THE COUNCIL of 20 June 2007, Official Journal of the European Union, (29.6.2007), L 171/1 - L 171/16

[19] “VOLVO S80 Instruktionsbok Web Edition” http://esd.volvocars.com/site/ownersinformation/MY11/S80/PDF/S80_owners manual_MY11_SE tp11740.pdf (accessed Jun 2011)

[20] G.M. Wallace, "EUROPEAN DIESEL FUEL - A REVIEW OF CHANGES IN PRODUCT QUALITY 1986-1989”, Preprint archive of the ACS Division of Fuel Chemistry, Vol 35(4) (1990) 1080 - 1099

[21] DIRECTIVE 2009/30/EC OF THE EUROPEAN PARLIAMENT AND OF THE COUNCIL of 23 April 2009, Official Journal of the European Union, (5.6.2009), L 140/88 - L 140/113

[22] L. Olsson, H. Sjövall, and R.J. Blint, Appl. Catal. B 81 (2008) 203-217

[23] A. Sultana, M. Haneda, T. Fujitani, and H. Hamada, Catal. Lett. 114 (2007) 96102

[24] K.-I. Shimizu, J. Shibata, H. Y., A. Satsuma, T. Hattori, Appl. Catal. B 30 (2001) 151-162

[25] Q. Wu, H. Gao, and H. He, J. Phys. Chem. B 110 (2006) 8320-8324

[26] I. Levin and D. Brandon, J. Am. Ceram. Soc., 81 (1998) 1995-2012

[27] R. Burch, J.P. Breen, and F.C. Meunier, Appl. Catal. B 39 (2002) 283-303

[28] T.C. Brüggemann, D.G. Vlachos, F.J. Keil, J. Catal. 283 (2011) 178-191

[29] B. Hammer, J.K. Nørskov, Adv. Catal. 45 (2000) 71-129

[30] B. Hammer, O.H. Nielsen and J.K. Nørskov, Catalysis Letters 46 (1997) 31-35

[31] Á. Logadóttir, J.K. Nørskov, Journal of Catalysis 220 (2003) 273-279

[32] Ton V. W. Janssens, Bjerne S. Clausen, Britt Hvolbæk, Hanne Falsig, Claus H. Christensen, Thomas Bligaard, and Jens K. Nørskov, Topics in Catalysis 44, (2007), $15-26$ 
[33] N. Jagtap, S.B. Umbarkar, P.Miquel, P. Granger , and M.K. Dongare, Appl. Catal. B 90 (2009) 416-425

[34] B. Kartheuser, B. K. Hodnett, Alfredo Riva, G. Centi, H. Matralis, M. Ruwet, Paul Grange, and N. Passarini, Ind. Eng. Chem. Res. 30 (1991) 2105-2113 


\section{Figure legends}

Figure 1. $\mathrm{NO}_{\mathrm{x}}(\mathbf{a})$ and $\mathrm{NH}_{3}$ (b) conversion profiles obtained over fresh $1-3 \% \mathrm{Ag} / \mathrm{Al}_{2} \mathrm{O}_{3}$ (black) and hydrothermally aged $1 \% \mathrm{Ag} / \mathrm{Al}_{2} \mathrm{O}_{3}$ (gray dotted) catalysts.

(c) Evolution of $\mathrm{NO}_{\mathrm{x}}$ conversion at 227 and $250{ }^{\circ} \mathrm{C}$ over $2 \% \mathrm{Ag} / \mathrm{Al}_{2} \mathrm{O}_{3}$ with $10 \mathrm{ppm} \mathrm{SO}_{2}$ in the feed.

(d) $\mathrm{NO}_{\mathrm{x}}$ and $\mathrm{NH}_{3}$ conversion profiles obtained over sulfur poisoned $1-3 \% \mathrm{Ag} / \mathrm{Al}_{2} \mathrm{O}_{3}$ catalysts.

(e) $\mathrm{NO}_{\mathrm{x}}$ and $\mathrm{NH}_{3}$ conversion profiles obtained over $1-3 \% \mathrm{Ag} / \mathrm{Al}_{2} \mathrm{O}_{3}$ catalysts after 40 min. regeneration at $670{ }^{\circ} \mathrm{C}$.

Reaction conditions: 500 ppm NO, 520 ppm NH$_{3}, 1200$ ppm H$_{2}, 8.3 \% \mathrm{O}_{2}, 7 \% \mathrm{H}_{2} \mathrm{O}$ in $\mathrm{Ar}, \mathrm{GHSV}=110000 \mathrm{~h}^{-1}$.

Figure 2. (a) $\mathrm{NO}_{\mathrm{x}}$ conversion profiles obtained over $2 \% \mathrm{Ag} / \mathrm{Al}_{2} \mathrm{O}_{3}$ after $10 \mathrm{~min}$. regeneration at $670{ }^{\circ} \mathrm{C}$ (dashed) and after $1 \mathrm{~min}$. regeneration at $670{ }^{\circ} \mathrm{C}$ in rich mixture (solid). Reaction conditions: 500 ppm NO, $520 \mathrm{ppm} \mathrm{NH}_{3}, 1200 \mathrm{ppm} \mathrm{H}_{2}, 8.3 \% \mathrm{O}_{2}, 7 \%$ $\mathrm{H}_{2} \mathrm{O}$ in $\mathrm{Ar}, \mathrm{GHSV}=110000 \mathrm{~h}^{-1}$.

(b) Dependence of shift of temperature of $50 \% \mathrm{NO}_{\mathrm{x}}$ conversion on the regeneration time. The 0 corresponds to no regeneration.

Figure 3. (a) Temperature profile of $4 \mathrm{~h}$. sulfation - $40 \mathrm{~min}$. regeneration experiment. (b) Temperature profile of 4 x $1 \mathrm{~h}$. sulfation - $10 \mathrm{~min}$. regeneration experiment. 
(c) $\mathrm{NO}_{\mathrm{x}}$ conversion profiles obtained over fresh $2 \% \mathrm{Ag} / \mathrm{Al}_{2} \mathrm{O}_{3}$ (solid line), $2 \% \mathrm{Ag} / \mathrm{Al}_{2} \mathrm{O}_{3}$ after $4 \mathrm{~h}$. with $10 \mathrm{ppm} \mathrm{SO}_{2}$ at $240{ }^{\circ} \mathrm{C}$ and $40 \mathrm{~min}$. regeneration at $670{ }^{\circ} \mathrm{C}$ (dotted line), after 4 cycles $1 \mathrm{~h}$. with $10 \mathrm{ppm} \mathrm{SO}_{2}$ at $240{ }^{\circ} \mathrm{C}$ and $10 \mathrm{~min}$. regeneration (dashed line).

Figure 4. Evolution of $\mathrm{NO}_{\mathrm{x}}$ conversion with time for first 9 cycles of the long term stability test of $2 \% \mathrm{Ag} / \mathrm{Al}_{2} \mathrm{O}_{3}$. Reaction conditions: 500 ppm NO, $1200 \mathrm{ppm} \mathrm{H}_{2}, 8.3 \%$ $\mathrm{O}_{2}, 7 \% \mathrm{H}_{2} \mathrm{O}$ in $\mathrm{Ar}, \mathrm{GHSV}=110000 \mathrm{~h}^{-1}$. Sulfation with $10 \mathrm{ppm} \mathrm{SO}_{2}$ for $1 \mathrm{~h}$. at $240{ }^{\circ} \mathrm{C}$, regeneration for $10 \mathrm{~min}$. at $670{ }^{\circ} \mathrm{C}$.

Figure 5. The scheme of $\mathrm{Ag} / \mathrm{Al}_{2} \mathrm{O}_{3}$ sulfation and regeneration.

Figure 6. (a) $\mathrm{NO}_{\mathrm{x}}$ conversion profiles obtained over fresh $2 \% \mathrm{Ag} / \mathrm{Al}_{2} \mathrm{O}_{3}$ (solid line), $2 \% \mathrm{Ag} / \mathrm{Al}_{2} \mathrm{O}_{3}$ after $4 \mathrm{~h}$. with $10 \mathrm{ppm} \mathrm{SO}_{2}$ at $240{ }^{\circ} \mathrm{C}$, followed by $40 \mathrm{~min}$. regeneration at $670{ }^{\circ} \mathrm{C}$ (dotted line) and after additional regeneration at $950{ }^{\circ} \mathrm{C}$ (dashed line).

(b) Temperature dependence of $\mathrm{NO}_{2}$ concentration at the reactor outlet obtained over fresh $2 \% \mathrm{Ag} / \mathrm{Al}_{2} \mathrm{O}_{3}$ (solid line), $2 \% \mathrm{Ag} / \mathrm{Al}_{2} \mathrm{O}_{3}$ after $4 \mathrm{~h}$. with $10 \mathrm{ppm} \mathrm{SO}_{2}$ at $240{ }^{\circ} \mathrm{C}$, followed by $40 \mathrm{~min}$. regeneration at $670{ }^{\circ} \mathrm{C}$ (dotted line) and after additional regeneration at $950{ }^{\circ} \mathrm{C}$ (dashed line). Reaction conditions: 500 ppm NO, $520 \mathrm{ppm} \mathrm{NH}_{3}$, $1200 \mathrm{ppm}_{2}, 8.3 \% \mathrm{O}_{2}, 7 \% \mathrm{H}_{2} \mathrm{O}$ in $\mathrm{Ar}, \mathrm{GHSV}=110000 \mathrm{~h}^{-1}$.

Figure 7. The most energetically favorable adsorption geometries for adsorption of $\mathrm{SO}_{2}, \mathrm{SO}_{3}$, and $\mathrm{SO}_{4}$ on $\gamma-\mathrm{Al}_{2} \mathrm{O}_{3}$ model surface (with corresponding adsorption energies). 
Table 1. Specific surface areas of tested catalysts as measured by BET.

\begin{tabular}{|c|c|c|}
\hline Catalyst & Treatment & $\mathrm{S}_{\mathrm{BET}}\left[\mathrm{m}^{2} / \mathrm{g}\right]$ \\
\hline $1 \% \mathrm{Ag} / \mathrm{Al}_{2} \mathrm{O}_{3}$ & - & 142 \\
\hline $1 \% \mathrm{Ag} / \mathrm{Al}_{2} \mathrm{O}_{3}$ & hydrothermal aging $\left(750^{\circ} \mathrm{C}, 16 \mathrm{~h}.\right)$ & 126 \\
\hline $2 \% \mathrm{Ag} / \mathrm{Al}_{2} \mathrm{O}_{3}$ & catalytic test (w/o deactivation) & 130 \\
\hline $2 \% \mathrm{Ag} / \mathrm{Al}_{2} \mathrm{O}_{3}$ & sulfation and 10 min. regen. @ $670{ }^{\circ} \mathrm{C}$ & 129 \\
\hline $2 \% \mathrm{Ag} / \mathrm{Al}_{2} \mathrm{O}_{3}$ & sulfation and 80 min. regen. @ $670{ }^{\circ} \mathrm{C}$ & 113 \\
\hline $2 \% \mathrm{Ag} / \mathrm{Al}_{2} \mathrm{O}_{3}$ & $\begin{array}{l}30 \text { cycles of } 1 \mathrm{~h} \text {. sulfation and } 10 \mathrm{~min} \text {. regen. } \\
\text { @ } 670^{\circ} \mathrm{C} \text {, followed by heating to } 950^{\circ} \mathrm{C}\end{array}$ & 121 \\
\hline $3 \% \mathrm{Ag} / \mathrm{Al}_{2} \mathrm{O}_{3}$ & - & 141 \\
\hline
\end{tabular}


Table 2. Adsorption energies and desorption temperatures of $\mathrm{SO}_{\mathrm{x}}$ for the most energetically favorable adsorption geometries in case of different adsorption sites.

\begin{tabular}{|c|c|c|c|c|c|c|c|c|c|c|}
\hline & \multicolumn{4}{|c|}{ Type II (metallic Ag) } & \multicolumn{6}{|c|}{ Type I (dispersed Ag) } \\
\hline & \multicolumn{2}{|c|}{$\operatorname{Ag}(111)$} & \multicolumn{2}{|c|}{$\operatorname{Ag}(211)$} & \multicolumn{2}{|c|}{$\gamma-\mathrm{Al}_{2} \mathrm{O}_{3}$} & \multicolumn{2}{|c|}{$\begin{array}{l}\text { Ag built in the } \gamma- \\
\mathrm{Al}_{2} \mathrm{O}_{3} \text { surface }\end{array}$} & \multicolumn{2}{|c|}{$\begin{array}{l}\text { Ag on the step of } \\
\gamma-\mathrm{Al}_{2} \mathrm{O}_{3}\end{array}$} \\
\hline & $\mathbf{E}_{\text {ads }}, \mathrm{eV}$ & $\mathbf{T}_{\text {des }}, \mathbf{K}$ & $\mathbf{E}_{\text {ads }}, \mathbf{e V}$ & $\mathbf{T}_{\text {des }}, \mathbf{K}$ & $\mathbf{E}_{\text {ads }}, \mathbf{e V}$ & $\mathbf{T}_{\text {des}}, \mathbf{K}$ & $\mathrm{E}_{\text {ads }}, \mathrm{eV}$ & $\mathbf{T}_{\text {des, }}, \mathbf{K}$ & $\mathbf{E}_{\text {ads }}, \mathbf{e V}$ & $\mathbf{T}_{\text {des }}, \mathbf{K}$ \\
\hline $\mathrm{SO}_{2}$ & \multicolumn{2}{|c|}{ not adsorbed } & -0.26 & 81 & -1.43 & 558 & -2.06 & 791 & -1.29 & 506 \\
\hline $\mathrm{SO}_{3}$ & -1.61 & 390 & -1.82 & 458 & -2.66 & 630 & -3.34 & 781 & -2.64 & 625 \\
\hline $\mathrm{SO}_{4}$ & -2.65 & 454 & -2.97 & 597 & -1.15 & 222 & -1.77 & 331 & -3.14 & 572 \\
\hline
\end{tabular}


Table 3. Energies of $\mathrm{HSO}_{\mathrm{x}}$ species in the gas phase and adsorbed on the most energetically favorable adsorption sites.

\begin{tabular}{|c|c|c|c|c|c|}
\hline Energy*, eV : & $\mathrm{HSO}_{2}$ & $\mathrm{HSO}_{3}$ & $\overline{\mathrm{H}_{2} \mathrm{SO}_{3}}$ & $\mathrm{HSO}_{4}$ & $\mathrm{H}_{2} \mathrm{SO}_{4}$ \\
\hline Gas phase & 0.29 & - & - & -1.48 & -3.39 \\
\hline $\begin{array}{l}\text { Adsorbed on } \gamma \text { - } \\
\mathrm{Al}_{2} \mathrm{O}_{3}\end{array}$ & Dissociates & -2.84 & Dissociates & -3.16 & Dissociates \\
\hline $\begin{array}{l}\text { Adsorbed on } \mathrm{Ag} \\
\text { built in the } \gamma \text { - } \\
\mathrm{Al}_{2} \mathrm{O}_{3}\end{array}$ & & & & & \\
\hline $\begin{array}{l}\text { Adsorbed on } \mathrm{Ag} \\
\text { (211) }\end{array}$ & 0.02 & Dissociates & -2.22 & -3.94 & -3.57 \\
\hline
\end{tabular}

* Energy of the $\mathrm{HSO}_{x}$ species is given with respect to $\mathrm{SO}_{2}(\mathrm{~g}), \mathrm{O}_{2}$ (g) and $\mathrm{H}_{2}(\mathrm{~g})$. 
Figure 1
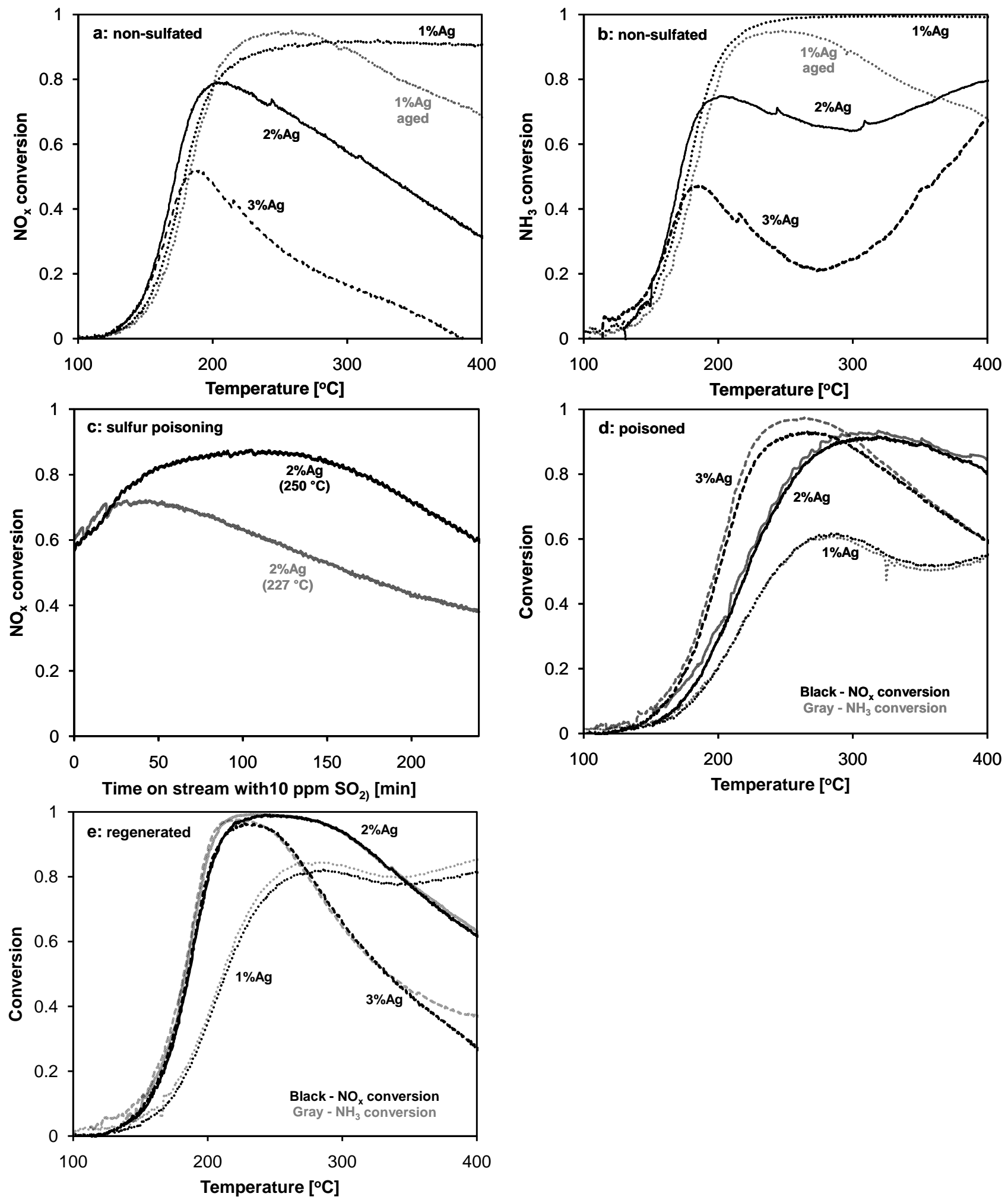
Figure 2
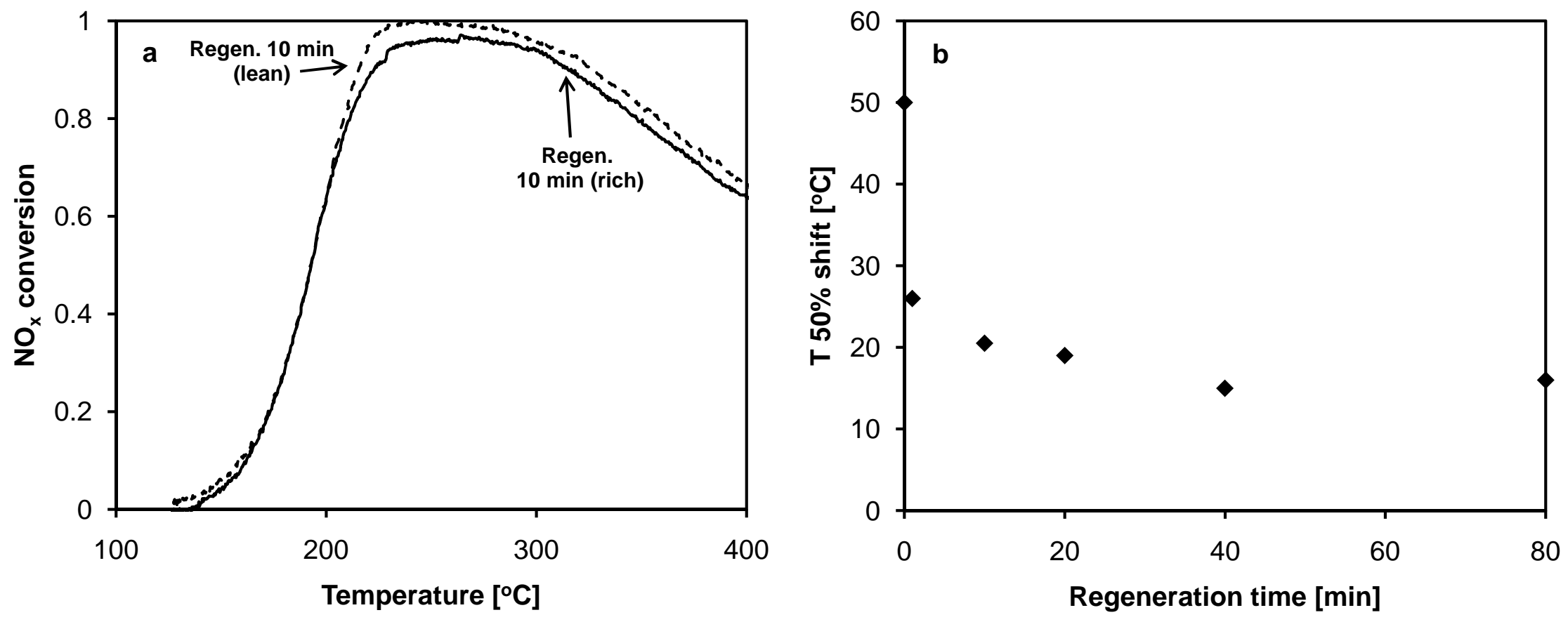
Figure 3
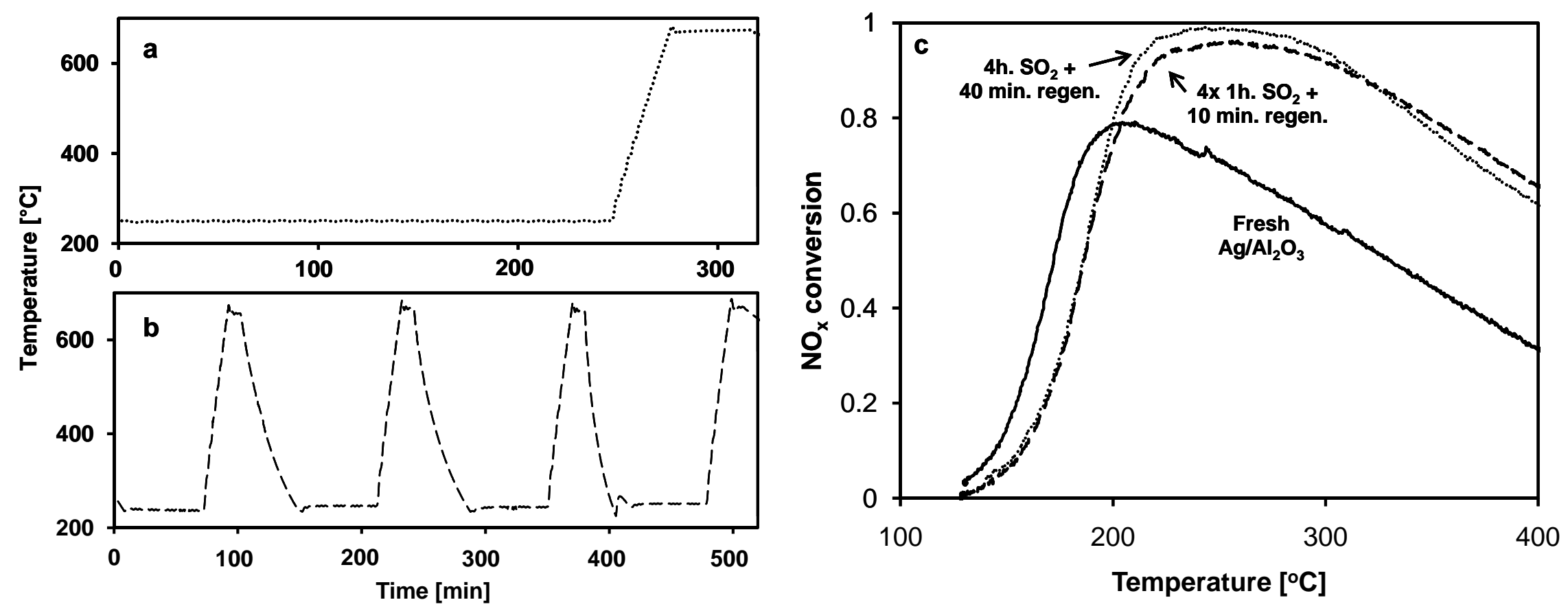
Figure 4

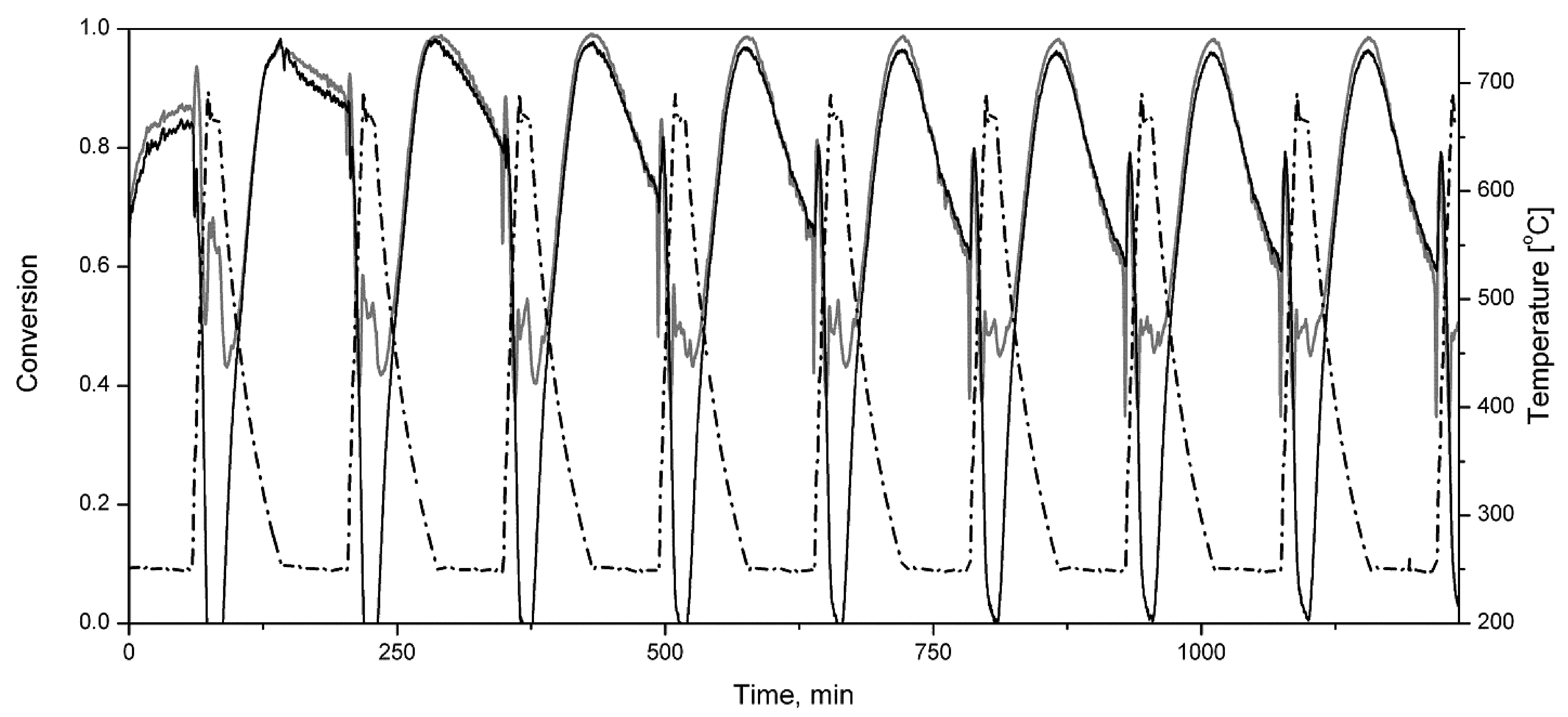




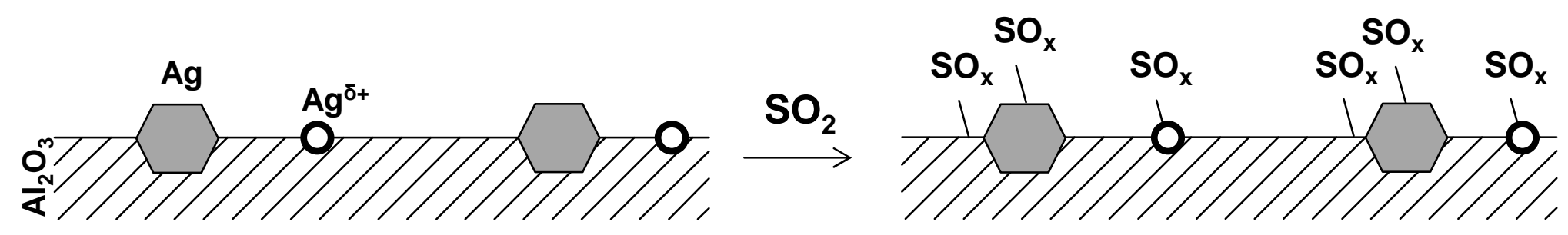

O - Type I active sites (highly dispersed Ag)

- Type II active sites (Ag nanoparticles)

\section{Regeneration}

$670^{\circ} \mathrm{C}$

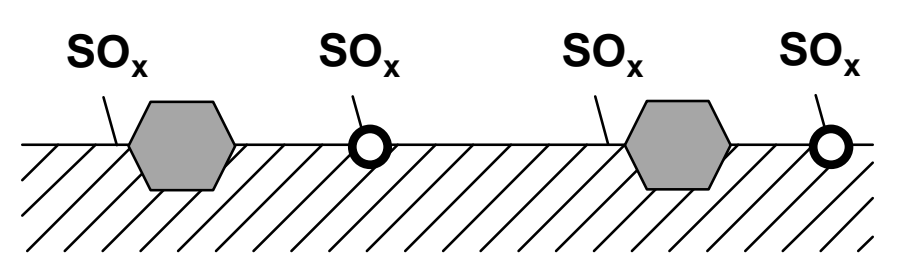


Figure 6
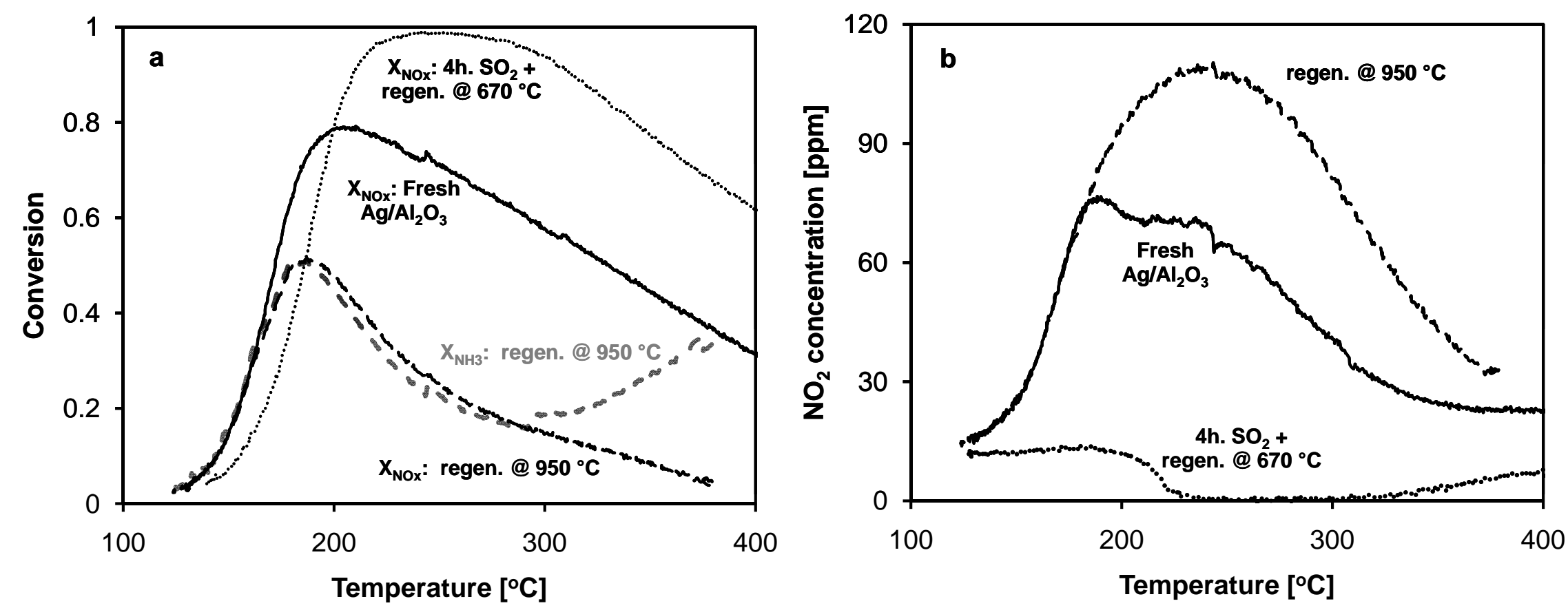


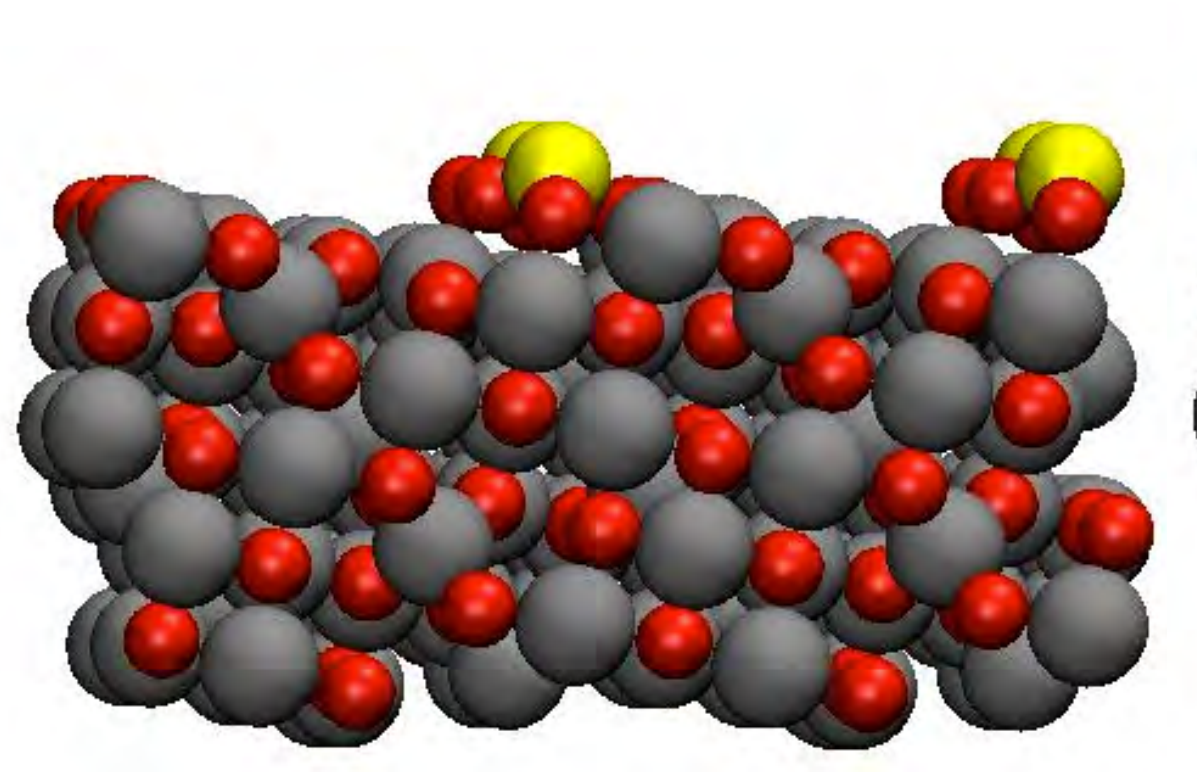

$\mathrm{SO}_{2} @ \mathrm{y}-\mathrm{Al}_{2} \mathrm{O}_{3}:-1.43 \mathrm{eV}$

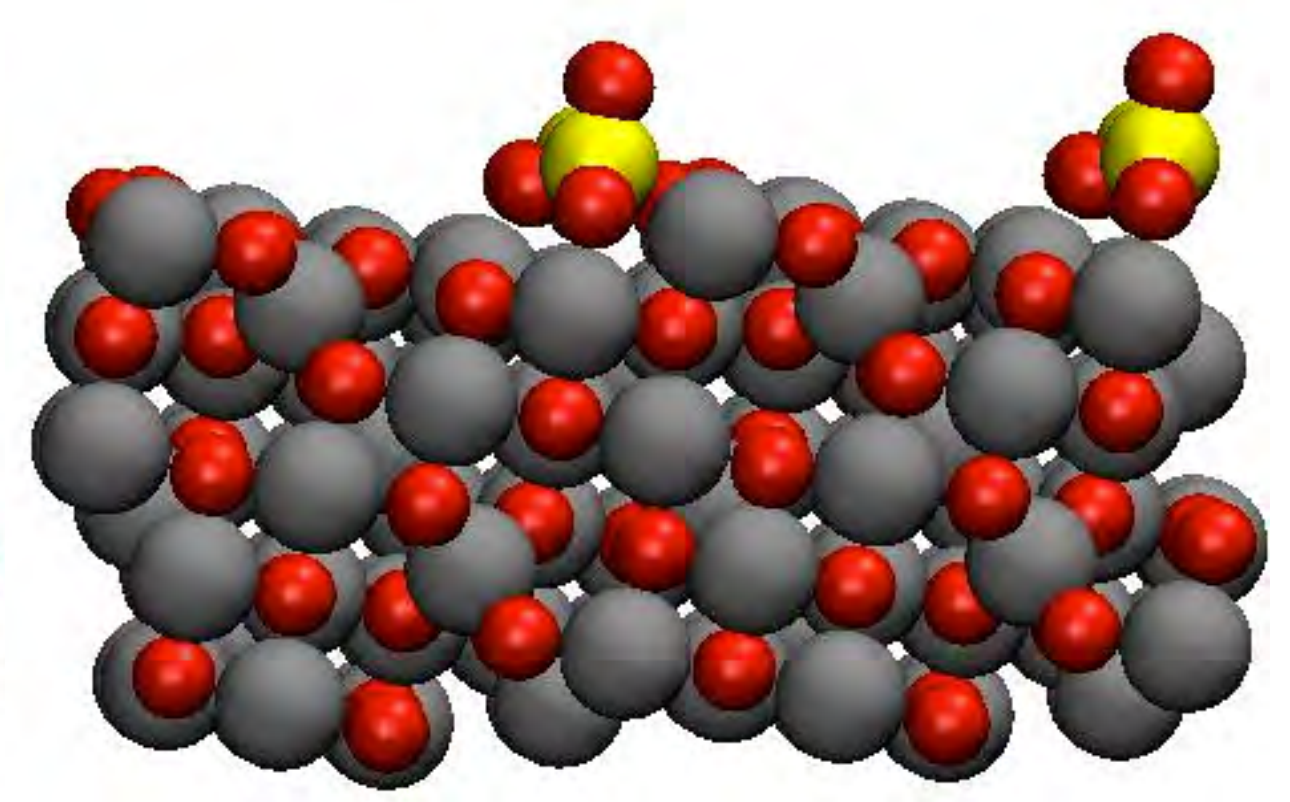

$\mathrm{SO}_{3} @ \mathrm{y}-\mathrm{Al}_{2} \mathrm{O}_{3}:-2.66 \mathrm{eV}$

$\mathrm{SO}_{4} @ \mathrm{y}-\mathrm{Al}_{2} \mathrm{O}_{3}:$ $-1.15 \mathrm{eV}$

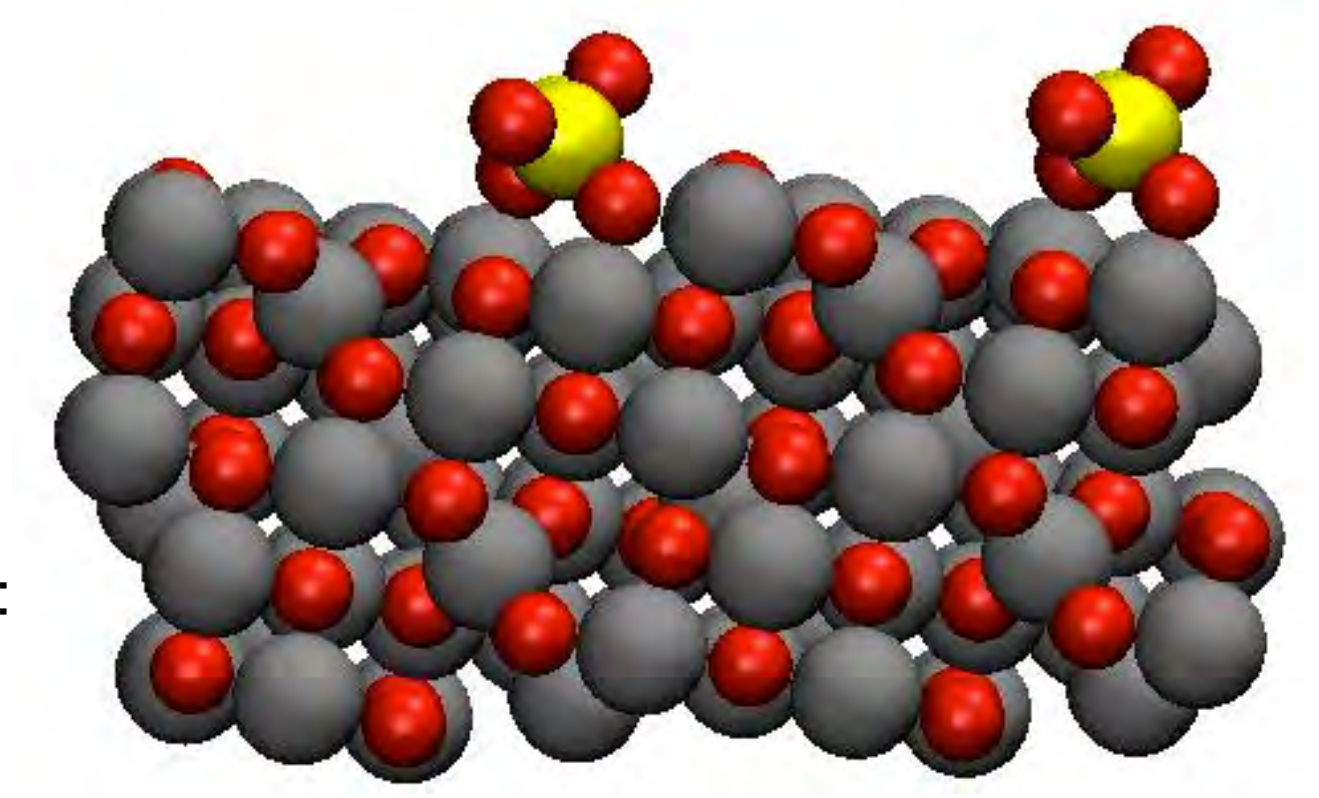

